\title{
Systematic Review \\ Systematic Review of Single-Fraction Stereotactic Body Radiation Therapy for Early Stage Non-Small-Cell Lung Cancer and Lung Oligometastases: How to Stop Worrying and Love One and Done
}

\author{
Austin J. Bartl ${ }^{1}$, Mary Mahoney ${ }^{2}{ }^{D}$, Mark W. Hennon ${ }^{3}$, Sai Yendamuri ${ }^{3}$, Gregory M. M. Videtic ${ }^{4}$, \\ Kevin L. Stephans ${ }^{4}$, Shankar Siva ${ }^{5}\left(\mathbb{D}\right.$, Mark K. Farrugia ${ }^{6}\left(\mathbb{D}\right.$, Sung Jun Ma ${ }^{6}$ and Anurag K. Singh ${ }^{6, *}$
}

check for updates

Citation: Bartl, A.J.; Mahoney, M.; Hennon, M.W.; Yendamuri, S.; Videtic, G.M.M.; Stephans, K.L.; Siva, S.; Farrugia, M.K.; Ma, S.J.; Singh, A.K. Systematic Review of Single-Fraction Stereotactic Body Radiation Therapy for Early Stage Non-Small-Cell Lung Cancer and Lung Oligometastases: How to Stop Worrying and Love One and Done. Cancers 2022, 14, 790. https:// doi.org/10.3390/cancers14030790 Academic Editors: Laura Cella, Giuseppe Palma and Andrew Hope

Received: 20 December 2021

Accepted: 1 February 2022

Published: 3 February 2022

Publisher's Note: MDPI stays neutral with regard to jurisdictional claims in published maps and institutional affiliations.

Copyright: (C) 2022 by the authors. Licensee MDPI, Basel, Switzerland. This article is an open access article distributed under the terms and conditions of the Creative Commons Attribution (CC BY) license (https:// creativecommons.org/licenses/by/ $4.0 /)$.
1 Jacobs School of Medicine and Biomedical Sciences, University at Buffalo, The State University of New York, Buffalo, NY 14203, USA; abart1@buffalo.edu

2 College of Medicine, State University of New York Upstate Medical University, Syracuse, NY 13210, USA; mahonmar@upstate.edu

3 Department of Thoracic Surgery, Roswell Park Comprehensive Cancer Center, Buffalo, NY 14203, USA; mark.hennon@roswellpark.org (M.W.H.); sai.yendamuri@roswellpark.org (S.Y.)

4 Department of Radiation Oncology, Cleveland Clinic Taussig Cancer Institute, Cleveland, OH 44195, USA; videtig@ccf.org (G.M.M.V.); stephak@ccf.org (K.L.S.)

5 Department of Radiation Oncology, Peter MacCallum Cancer Centre, Melbourne, VIC 3000, Australia; shankar.siva@petermac.org

6 Department of Radiation Medicine, Roswell Park Comprehensive Cancer Center, Buffalo, NY 14203, USA; mark.farrugia@roswellpark.org (M.K.F.); sungjun.ma@roswellpark.org (S.J.M.)

* Correspondence: anurag.singh@roswellpark.org; Tel.: +1-716-845-5715

Simple Summary: Adoption of single-fraction stereotactic body radiation therapy for lung tumors has been limited among different institutions even during the coronavirus disease 2019 (COVID-19) pandemic. Potential reasons may include a lack of familiarity and concerns regarding potential toxicities. To address this knowledge gap, we performed a systematic review of prospective literature on single-fraction SBRT. Our PubMed search of prospective trials resulted in nine studies that showed favorable local control and survival outcomes among peripheral tumors. Many toxicities were grade $1-2$, with $0-17 \%$ of patients experiencing grade $\geq 3$ toxicity. Encouraging outcomes suggest that the utility of single-fraction stereotactic body radiation therapy may extend beyond the current COVID-19 pandemic.

Abstract: Adoption of single-fraction lung stereotactic body radiation therapy (SBRT) for patients with medically inoperable early stage non-small-cell lung cancer (NSCLC) or oligometastatic lung disease, even during the coronavirus disease 2019 (COVID-19) pandemic, was limited despite encouraging phase II trial results. Barriers to using single-fraction SBRT may include lack of familiarity with the regimen and lack of clarity about the expected toxicity. To address these concerns, we performed a systematic review of prospective literature on single-fraction SBRT for definitive treatment of early stage and oligometastatic lung cancer. A PubMed search of prospective studies in English on single-fraction lung SBRT was conducted. A systematic review was performed of the studies that reported clinical outcomes of single-fraction SBRT in the treatment of early stage non-small-cell lung cancer and lung oligometastases. The current prospective literature including nine trials supports the use of single-fraction SBRT in the definitive treatment of early stage peripheral NSCLC and lung oligometastases. Most studies cite local control rates of $>90 \%$, mild toxicity profiles, and favorable survival outcomes. Most toxicities reported were grade $1-2$, with grade $\geq 3$ toxicity in $0-17 \%$ of patients. Prospective trial results suggest potential consideration of utilizing single-fraction SBRT beyond the COVID-19 pandemic.

Keywords: lung; NSCLC; lung oligometastases; SABR; SBRT; single fraction 


\section{Introduction}

During the coronavirus disease 2019 (COVID-19) pandemic, treatment recommendations for cancer have emphasized delivering high-quality care while minimizing in-person interactions between patients and healthcare providers [1]. For medically inoperable patients with early stage non-small cell lung cancer (NSCLC) or lung oligometastases, a range of treatment guidelines has supported stereotactic body radiation therapy (SBRT) [2-6]. Several prospective studies have substantiated the therapeutic utility of SBRT as a surgical alternative, with long-term local control rates of $\sim 90 \%$ at 5 years [7-9]. Prospective trials $[10,11]$ and retrospective studies [12-14] showed similar outcomes for NSCLC patients treated with single- and multi-fraction SBRT. The National Comprehensive Cancer Network (NCCN) guidelines support single-fraction lung SBRT for peripheral NSCLC [15]. The lungs are the first site of distant metastatic disease for many malignant tumors. A randomized trial in pulmonary oligometastases suggested similar outcomes at 1 year post single- or multi-fraction SBRT [16].

Despite this evidence, prior to and even during COVID-19, adoption of single-fraction SBRT was modest [17-19]. Potential explanations include: lack of familiarity with the evidence and lack of clarity about the expected toxicity [4]. To address these concerns, we performed a systematic review of prospective literature on single-fraction SBRT for definitive treatment of early-stage and oligometastatic lung cancer patients.

\section{Materials and Methods}

A comprehensive PubMed search of published journal articles written in English related to single-fraction lung SBRT was performed using keywords "single fraction", "stereotactic body radiation therapy", "SBRT", "SABR", "lung cancer", "NSCLC", and "oligometastatic". The inclusion criteria were (1) prospective studies and (2) studies citing clinical outcomes on early stage NSCLC or lung oligometastases definitively treated with SBRT in a single fraction. Trials comparing several fractionation schedules that included a single-fraction regimen, and studies not available in the PubMed database but satisfying the inclusion criteria, were also included in this review. Exclusion criteria were (1) retrospective studies, case reports, meta-analyses, or review articles; (2) studies only using multi-fractionated SBRT regimens; and (3) studies involving carbon ion radiotherapy. Our report follows the Preferred Reporting Items for Systematic Reviews and Meta-Analyses (PRISMA) guideline [20]. The literature search was conducted and completed in October 2021. Three reviewers determined the eligibility of studies for inclusion based on the above selection criteria.

\section{Results}

Nine studies met criteria for this analysis [10,11,16,21-26]. Publication years ranged from 2003 to 2021. The PRISMA decision tree is shown in Figure 1.

\subsection{Medically Inoperable Early Stage NSCLC: Local Control and Survival}

Early single-fraction publications addressed the feasibility, safety, and efficacy of this SBRT schedule, with outcomes showing encouraging local control (LC) rates, tolerable toxicity profiles, and low rates of distant failures $[22,23,25]$. Mature studies of singlefraction SBRT for early stage NSCLC confirmed the earlier excellent rates of local control and minimal rates of grade 3 or higher toxicity $[10,11]$. Table 1 summarizes each study's characteristics and outcomes. 


\section{$\mathrm{N}=190,981$}

Literature search of SBRT/SABR and lung

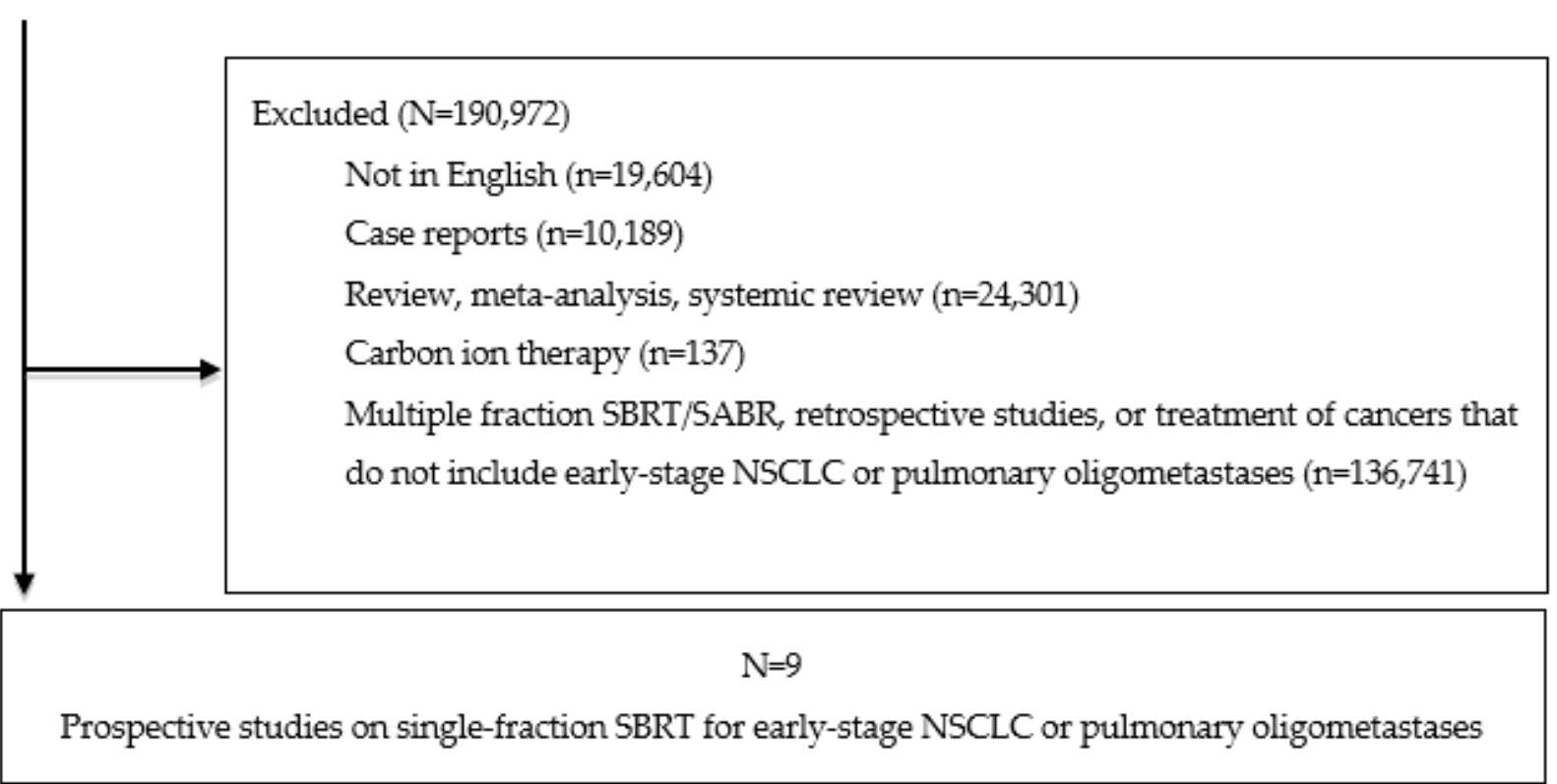

SBRT: stereotactic body radiation therapy; SABR: stereotactic ablative radiotherapy; NSCLC: nonsmall cell lung cancer

Figure 1. Study selection flow diagram.

Radiation Therapy Oncology Group (RTOG) 0915 randomized 84 medically inoperable patients with peripheral T1-2NOM0 NSCLC to receive either 34 Gray (Gy) in a single fraction or 48 Gy over four consecutively delivered fractions [11]. There were no significant differences in 5 year primary tumor failure rates $(11 \% ; 7 \%)$, distant failures $(38 ; 41 \%)$, median progression-free survival (PFS; 2.6 and 2.8 years), and median overall survival (OS; 4.1 and 4.6 years) for 34 and 48 Gy, respectively [11].

Singh et al., in a multi-institutional phase II trial, randomized 98 medically inoperable patients with peripheral T1-2N0M0 NSCLC to $30 \mathrm{~Gy}$ in a single fraction or $60 \mathrm{~Gy}$ in three fractions [10]. There were no significant differences in 2 year rates of: LC (94.9\% and $97.1 \%)$, regional nodal failure ( $8 \%$ and $16 \%$ ), distant failure $(13 \%$ and $19 \%)$, PFS $(65 \%$ and $50 \%)$, or OS $(73 \%$ and $62 \%)$ [10].

\subsection{Lung Oligometastases: Local Control and Survival}

In prospective trials investigating lung oligometastases, tumor control, regression, relapse, distant-site failure, DFS, PFS, and OS, results were collected and documented. Tumor control measures and survival outcomes are listed in Table 2. 
Table 1. Study characteristics, local control, and survival outcomes for early stage non-small-cell lung cancer (NSCLC).

\begin{tabular}{|c|c|c|c|c|c|c|c|c|c|c|c|c|}
\hline Study & No. & $\begin{array}{c}\mathrm{F} / \mathrm{u} \\
\text { (Median) }\end{array}$ & Age (Median) & Location & Stage & Dose/Fx & LC & RC & PFS & DFS & os & Distant Failure \\
\hline $\begin{array}{l}\text { Hof et al., } 2003 \\
{[\text { [23] }}\end{array}$ & 10 & 14.9 & 71 & NA & T1-2N0M0 & $19-26$ Gy $/ 1 \mathrm{fx}$ & $\begin{array}{l}80 \% \text { at follow-up, } 50 \% \\
\text { remained locally } \\
\text { controlled }\end{array}$ & NA & $\begin{array}{l}\text { LRFS } 89 \% \text { at } 12 \\
\text { months, } 71.1 \% \\
\text { at } 24 \text { months }\end{array}$ & NA & $\begin{array}{l}80 \% \text { after } 12 \\
\text { months, } 64 \% \text { at } \\
24 \text { months }\end{array}$ & $\begin{array}{c}\text { Systemic } \\
\text { metastases in } 5 \\
\text { patients; time until } \\
\text { diagnosis was } \\
\text { median of } 7.2 \\
\text { months. }\end{array}$ \\
\hline $\begin{array}{l}\text { Fritz et al., } \\
2006 \text { [22] }\end{array}$ & 33 & 18 & 72 & $P$ & Stage 1 & $30 \mathrm{~Gy} / 1 \mathrm{fx}$ & $\begin{array}{c}94 \% \text {; probability at } 4 \\
\text { years, } 83 \%\end{array}$ & NA & NA & NA & $\begin{array}{c}\text { Median } 20.4 \\
\text { months. } 83 \% \text { at } 1 \\
\text { year, } 63 \% \text { at } 2 \\
\text { years, } 53 \% \text { at } 3 \\
\text { years, } 39 \% \text { at } 4 \\
\text { years. } \\
\end{array}$ & NA \\
\hline $\begin{array}{l}\text { Le et al., } 2006 \\
{[25]}\end{array}$ & 20 & 18 & 73 & $\mathrm{C}$ and $\mathrm{P}$ & T1-2N0M0 & $15-30$ Gy / 1 fx & $\begin{array}{c}\text { Overall 1-year FFLR, } \\
67 \% \text { - } 1 \text {-year FFLR } \\
100 \% \text { T1 tumors, } 83 \% \\
\text { T2 tumors }>20 \mathrm{~Gy}, \\
51 \% \text { T2 tumors }<20 \\
\text { Gy; } 1 \text {-year FFLR all } \\
\text { NSCLC tumors } 91 \% \\
>20 \text { Gy and } 54 \%<20 \\
\text { Gy }\end{array}$ & NA & NA & NA & $85 \%$ at 1 year & NA \\
\hline $\begin{array}{l}\text { Videtic et al., } \\
2018 \text { (RTOG } \\
\text { 0915) [11] }\end{array}$ & 84 & 4 years & 75 & $\mathrm{P}$ & T1-2N0M0 & $\begin{array}{l}34 \mathrm{~Gy} / 1 \mathrm{fx} \text { or } \\
48 \mathrm{~Gy} / 4 \mathrm{fx}\end{array}$ & $\begin{array}{c}97 \% \text { arm } 1,93 \% \text { arm } 2 \\
\text { at } 1 \text { year; } 2 \text {-year } \\
\text { primary failure rate, } \\
2.6 \% \text { arm } 1,2.2 \% \text { arm } \\
\text { 2. } 5 \text {-year primary } \\
\text { failure rate, } 11 \% \text { arm } \\
1,7 \% \text { arm } 2\end{array}$ & NA & $\begin{array}{c}\text { Median } 2.6 \\
\text { years arm } 1 \\
2.8 \text { years arm } 2 . \\
19 \% \text { arm } 1, \\
33 \% \text { arm } 2 \text { at } 5 \\
\text { years. }\end{array}$ & $\begin{array}{c}77 \% \text { arm } 1, \\
84 \% \text { arm } 2 \text { at } \\
1 \text { year. } 56 \% \\
\text { arm } 1,71 \% \\
\text { in arm } 2 \text { at } 2 \\
\text { years }\end{array}$ & $\begin{array}{c}85 \% \text { arm } 1,91 \% \\
\text { arm } 2 \text { at } 1 \text { year. } \\
61 \% \text { arm } 1,78 \% \\
\text { in arm } 2 \text { at } 2 \\
\text { years. Median } 4.1 \\
\text { years arm } 1,4.6 \\
\text { years arm } 2.30 \% \\
\text { arm } 1,41 \% \text { arm } 2 \\
\text { at } 5 \text { years }\end{array}$ & $\begin{array}{c}38 \% \text { arm } 1,41 \% \\
\text { arm } 2 .\end{array}$ \\
\hline $\begin{array}{l}\text { Singh et al., } \\
2019 \text { [10] }\end{array}$ & 98 & 54 & 71 & $\mathrm{P}$ & T1-2N0M0 & $\begin{array}{c}30 \mathrm{~Gy} / 1 \mathrm{fx} \text { or } \\
60 \mathrm{~Gy} / 3 \mathrm{fx}\end{array}$ & $\begin{array}{l}95 \% \text { arm } 1,97 \% \text { in } \\
\text { arm } 2 \text { at } 2 \text { years }\end{array}$ & $\begin{array}{c}\text { 2-year regional } \\
\text { nodal failure } \\
\text { rate, } 8 \% \text { arm } 1, \\
16 \% \text { arm } 2\end{array}$ & $\begin{array}{c}65 \% \text { arm } 1 \\
50 \% \text { arm } 2 \text { at } 2 \\
\quad \text { years }\end{array}$ & NA & $\begin{array}{l}73 \% \text { arm } 1,62 \% \\
\text { arm } 2 \text { at } 2 \text { years }\end{array}$ & $\begin{array}{l}13 \% \text { arm } 1,19 \% \\
\text { arm } 2 \text { at } 2 \text { years }\end{array}$ \\
\hline
\end{tabular}

No.: number of patients; f/u: follow up; fx: fraction; LC: local control; RC: regional control; PFS: progression-free survival; DFS: disease-free survival; OS: overall survival; NA: not available; LRFS: local-recurrence-free survival; C: central; P: peripheral; FFLR: freedom from local recurrence; NSCLC: non-small-cell lung cancer; RTOG: Radiation Therapy Oncology Group. 
Table 2. Study characteristics, local control, and survival outcomes for pulmonary metastases.

\begin{tabular}{|c|c|c|c|c|c|c|c|c|c|c|c|}
\hline Study & No. & $\begin{array}{c}\text { F/u } \\
\text { (Median) }\end{array}$ & $\begin{array}{c}\text { Age } \\
\text { (Median) }\end{array}$ & Location & Dose/Fx & LC & RC & PFS & DFS & OS & Distant Failure \\
\hline $\begin{array}{l}\text { Fritz et al., } \\
2006 \text { [22] }\end{array}$ & 25 & 22 & 65 & $\mathrm{P}$ & $30 \mathrm{~Gy} / 1 \mathrm{fx}$ & $\begin{array}{c}87 \% \text {; probability at } \\
5 \text { years, } 80 \%\end{array}$ & NA & NA & NA & $\begin{array}{c}\text { Median } 26 \text { months. } \\
97 \% \text { at } 1 \text { year, } 73 \% \text { at } \\
2 \text { years, } 42 \% \text { at } 3 \\
\text { years, } 42 \% \text { at } 2 \text { years, } \\
42 \% \text { at } 5 \text { years }\end{array}$ & NA \\
\hline $\begin{array}{c}\text { Le et al., } 2006 \\
{[25]}\end{array}$ & 12 & 18 & 73 & $\mathrm{C}$ and $\mathrm{P}$ & $15-30 \mathrm{~Gy} / 1 \mathrm{fx}$ & $\begin{array}{c}\text { Overall 1-year } \\
\text { FFLR, 25\%. 1-year } \\
\text { FFLR } 44 \% \text { > } 20 \text { Gy }\end{array}$ & NA & NA & NA & $56 \%$ at 1 year & NA \\
\hline $\begin{array}{l}\text { Filippi et al., } \\
2014 \text { [21] }\end{array}$ & 67 & 24 & NA & $\mathrm{P}$ & $26 \mathrm{~Gy} / 1 \mathrm{fx}$ & $\begin{array}{c}93 \% \text { at } 1 \text { year, } 88 \% \\
\text { at } 2 \text { years; local } \\
\text { failures, } 11 \% \text { of } \\
\text { patients. }\end{array}$ & NA & $\begin{array}{l}72 \% \text { at } 1 \text { year, } \\
55 \% \text { at } 2 \text { years }\end{array}$ & NA & $\begin{array}{c}85 \% \text { at } 1 \text { year, } 71 \% \text { at } \\
2 \text { years. CSS } 90 \% \text { at } 1 \\
\text { year, } 76 \% \text { at } 2 \text { years }\end{array}$ & $\begin{array}{c}55 \% \text { of patients, } \\
\text { at median of } 8 \\
\text { months } \\
\text { post-radiation }\end{array}$ \\
\hline $\begin{array}{c}\text { Siva et al., } 2021 \\
\text { [16] }\end{array}$ & 87 & 36.5 & 66.6 (mean) & $\mathrm{P}$ & $\begin{array}{c}28 \mathrm{~Gy} / 1 \mathrm{fx} v \mathrm{vs} \\
48 \mathrm{~Gy} / 4 \mathrm{fx}\end{array}$ & $\begin{array}{c}\text { 1-year FFLR: } 93 \% \\
\text { vs } 95 \% \text { at } 1 \text { year, } \\
64 \% \text { vs } 80 \% \text { at } 3 \\
\text { years }\end{array}$ & NA & NA & $\begin{array}{l}\text { Median } 14.3 \\
\text { months vs. } \\
13.2 \text { months }\end{array}$ & $\begin{array}{c}95 \% \text { vs } 93 \% \text { at } 1 \text { year, } \\
81 \% \text { vs. } 67 \% \text { at } 3 \\
\text { years }\end{array}$ & $\begin{array}{l}\text { Median time to } \\
\text { distant failure: } \\
16.0 \text { months vs } \\
14.5 \text { months }\end{array}$ \\
\hline
\end{tabular}


Hof et al. treated 61 metastatic patients with single-fraction SBRT ranging 12-30 Gy [24]. Median follow-up time was 14 months [24]. Long-term local tumor control was not achieved for metastases treated with $<24 \mathrm{~Gy}$, whereas the local progression-free rate (LPFR) for metastases treated with $\geq 24 \mathrm{~Gy}$ was $78 \%$ after 36 months [24]. Additionally, there was a trend of better local control for tumors $\leq 10 \mathrm{~cm}^{3}$ at a follow-up of 3 years, and the difference became more evident with radiation $\geq 26$ Gy [24].

Filippi et al. treated 67 patients with peripherally located metastatic lung tumors with $26 \mathrm{~Gy}$ in a single fraction [21]. Median follow-up time was 24 months [21]. Local failures were noted in $11 \%$ of patients [21]. Systemic failure occurred in 55\% of patients at a median of 8 months after radiation, with no difference in the crude systemic failure rate between patients with a single tumor and those with 2-3 metastases [21].

The phase II SAFRON II trial randomized 87 patients with 133 pulmonary metastases to either $28 \mathrm{~Gy}$ in a single fraction or $48 \mathrm{~Gy}$ in four fractions [16]. No significant differences were found between the multi- and single-fraction arms for freedom from local failure $95 \%$ versus $93 \%, p=0.13)$, OS (95\% versus $93 \%, p=0.44)$, or median disease-free survival (13.2 versus 14.3 months, $p>0.99)[16]$.

\subsection{Toxicity of SBRT in Primary NSCLC and Lung Oligometastases}

Table 3 summarizes the reported toxicity in these studies for both early stage NSCLC and lung oligometastases. It demonstrates overall favorable toxicity profiles with singlefraction SBRT.

Table 3. Toxicity results for early stage non-small-cell lung cancer (NSCLC) and pulmonary oligometastases.

\begin{tabular}{|c|c|c|c|}
\hline Study & Grade 1-2 Toxicity & Grade $\geq 3$ Toxicity & Toxicity Notes \\
\hline Whyte et al., 2003 [26] & NA & $0 \%$ & $\begin{array}{l}1 \text { COPD exacerbation, } 4 \\
\text { pneumothoraxes } \mathrm{s} / \mathrm{p} \text { fiducial } \\
\text { placement }\end{array}$ \\
\hline Hof et al., 2003 [23] & $\begin{array}{l}\text { NA; normal-perifocal tissue } \\
\text { reaction, } 70 \%\end{array}$ & Grade $>2,0 \%$ & $\begin{array}{c}\text { Some dyspnea reported, no PFT } \\
\text { performed }\end{array}$ \\
\hline Fritz et al., 2006 [22] & $\begin{array}{l}\text { Grade } 1 \text { radiation dermatitis, } 7 \% \text {; } \\
\text { asymptomatic radiation } \\
\text { pneumonitis via CT at } 6 \text { months, } \\
\quad 73 \%\end{array}$ & $0 \%$ & $\begin{array}{l}\text { NSCLC patients pneumonitic } \\
\text { alterations with asymptomatic, } \\
\text { temporary pleural effusions, } 24 \% \text {; } \\
\text { no changes in respiratory function }\end{array}$ \\
\hline Le et al., 2006 [25] & $\begin{array}{c}\text { Grade } 2 \text { pleural effusions, } \\
\text { pneumonitis, radiation-induced } \\
\text { atrial fibrillation, } 12.5 \%\end{array}$ & $\begin{array}{c}\text { Grade } 3 \text { pneumonitis, 3\%; Grade } \\
\text { 4,0\%; Grade } 5 \text { pneumonitis, } \\
\text { pleural effusions, } \\
\text { tracheoesophageal fistula, } 9 \%\end{array}$ & $\begin{array}{l}3 \text { post-treatment deaths; all } \\
\text { received prior chemotherapy, } 2 \\
\text { prior radiation therapy }\end{array}$ \\
\hline $\begin{array}{c}\text { Videtic et al., } 2019 \text { (RTOG 0915) } \\
\text { [11] }\end{array}$ & $\begin{array}{c}1 \text { additional Grade } 1 \text { AE arm } 1,1 \\
\text { Grade } 2 \text { AE (previous Grade 1) } \\
\text { arm } 2\end{array}$ & $\begin{array}{l}\text { Current rates: Grade } \geq 32.6 \% \text { arm } \\
\qquad 1,11.1 \% \text { arm } 2\end{array}$ & $\begin{array}{c}\text { Reported toxicities: DLCO } \\
\text { changes, pneumonitis, PFT } \\
\text { changes; } 1 \text { treatment-related } \\
\text { deaths (arm 2) }\end{array}$ \\
\hline Singh et al., 2019 [10] & Grade $1-2,22 \%$ arm $1,20 \%$ arm 2 & $\begin{array}{c}\text { Grade } 3,17 \% \text { arm } 1,15 \% \text { arm } 2 ; \\
\text { no Grade } 4 \text { or } 5\end{array}$ & $\begin{array}{l}\text { Better social functioning, fewer } \\
\text { constitutional symptoms, less } \\
\text { dyspnea arm } 1 .\end{array}$ \\
\hline Hof et al., 2007 [24] & $\begin{array}{c}\text { Grade } 1-2,0 \% \text {; normal perifocal } \\
\text { tissue changes, } 70 \%\end{array}$ & $\begin{array}{l}\text { Grade } 3 \text { pneumonitis requiring } \\
\text { treatment and supplemental } \\
\text { oxygen, } 5 \% \text {. Grade } 4 \text { or higher, } 0 \%\end{array}$ & None \\
\hline Filippi et al., 2014 [21] & Grade 1, 10\%. & Grade $2-3$ late, $12 \%$ & $\begin{array}{c}\text { Peripheral lesions with late chest } \\
\text { wall toxicity, } 9 \% \text { ( } 2 \text { rib fractures, } 4 \\
\text { chronic chest pain) }\end{array}$ \\
\hline Siva et al., 2021 [16] & NA & $\begin{array}{l}\text { 3-5\%; } 1 \text { patient with interstitial } \\
\text { lung disease received } \\
\text { multi-fraction SBRT and had } \\
\text { grade } 5 \text { treatment-related hypoxia } \\
\text { and radiation pneumonitis }\end{array}$ & $\begin{array}{l}\text { Radiation dermatitis and } \\
\text { esophagitis were more common in } \\
\text { multi-fraction SBRT arm }\end{array}$ \\
\hline
\end{tabular}


The primary endpoint of RTOG 0915 was the rate of grade $\geq 3$ protocol-specified adverse events (psAEs) at 1 year. Grade 3 or higher toxicities were $2.6 \%$ with 34 Gy and $11.1 \%$ with 48 Gy [11]. Based on pre-specified rules, since there was less nominal toxicity with comparable primary tumor control, single fraction was selected as the arm for future study [11].

Singh et al. used rates of Common Terminology Criteria for Adverse Events, with thoracic grade 3 or higher at 1 year as the primary study endpoint [10]. Thoracic grade 3 AEs were reported in $17 \%$ and $15 \%$ of patients treated with one or three fractions, respectively [10]. Thoracic grade 1-2 AEs were seen in $22 \%$ and $20 \%$ in patients with one and three fractions, respectively [10]. There were no grade 4 or 5 AEs [10]. There were no reported differences in overall quality of life measures or in pulmonary function testing between treatment arms; however, single-fraction patients had significantly better social functioning, fewer constitutional symptoms, and less dyspnea [10].

SAFRON II found no significant differences in adverse events [16]. There were two grade 3 or higher AEs at 1 year in the single-fraction arm and one (grade 5) in the multifraction arm [16]. Chest wall pain (for any grade) was not significantly different but nominally less in the single-fraction arm [16]. There were no significant differences observed in patient-reported outcomes [16].

Le et al. conducted a single-fraction SBRT study in a previously treated population [25]. There were three post-treatment deaths; all patients had received prior chemotherapy and two had received prior radiation therapy [25]. The two factors most associated with significant treatment-related toxicity were prior thoracic radiation therapy or chemotherapy, either before or after SBRT [25]. Most patients with grade 2 or greater toxicity had centrally located tumors and/or PTV > $50 \mathrm{cc}$ [25]. This study suggested that $25 \mathrm{~Gy}$ in a single fraction was well-tolerated in previously untreated patients; however, single-fraction SBRT was too toxic in patients with prior thoracic radiation and/or chemotherapy, especially those with large or central tumors [25].

\section{Discussion}

This systematic review supports the use of single-fraction SBRT as a definitive treatment for early stage peripheral NSCLC or lung oligometastases with local control rates $>90 \%$, mild toxicity profiles, and favorable survival outcomes compared to multi-fraction approaches. We shared this analysis with the NCCN and are pleased to note that the updated guidelines [15] removed both tumor size and a distance of less than $2 \mathrm{~cm}$ from the chest wall as a factor in determining eligibility for single-fraction SBRT.

Evidence for single-fraction SBRT in these patients comes from RTOG 0915 and Roswell Park phase II randomized studies that compared single-fraction and hypo-fractionated SBRT regimens $[10,11]$. Both studies reported comparable local control rates, PFS, OS, late toxicities, and overall quality of life measures between the single- and multi-fraction treatment arms $[10,11]$. These findings align with the European Society for Radiotherapy and Oncology-American Society for Radiation Oncology (ESTRO/ASTRO) guidelines, encouraging the consideration of single-fraction SBRT during the ongoing COVID-19 pandemic $[27,28]$.

Data on the use of single fraction since the beginning of the pandemic are limited. Prior to the pandemic, utilization of single fraction was extremely limited $[19,29]$. Hesitation to adopt single-fraction SBRT may have several causes: lack of familiarity with the evidence and lack of clarity about the expected toxicity [4]. Additionally, in countries with a feefor-service payment model such as the United States, another factor may be diminished reimbursement for single-fraction regimens.

A survey of radiation oncologists in 2013 revealed that only 1\% used single-fraction SBRT [29]. Consequently, the number of radiation oncologists with extensive personal experience with single fraction is limited. Anecdotally, based on number of queries that we received, more institutions have started to treat select patients with single-fraction SBRT.

Recent guidance on United Kingdom practice captures the concerns about toxicity and a lack of phase III data to justify single-fraction SBRT. The United Kingdom authors advised 
following the NCCN guidelines (prior to the 2022 update) and utilizing single fraction in patients with peripheral tumors that are $\leq 2 \mathrm{~cm}$ and $>1 \mathrm{~cm}$ from the chest wall [27]. The authors cited the evidence and noted in limitations that the data are only based on phase II data. However, for tumors within $2.5 \mathrm{~cm}$ of the chest wall, the authors suggested three fractions while stating that the "effect of fractionation schedules on chest wall toxicity has not been investigated in prospective trials". The prospective SAFRON II trial found that chest wall pain (for any grade) was not significantly different but nominally less in the single-fraction arm [16]. In both RTOG 0915 and the prospective trials by Singh et al., chest wall toxicity (CWT) did not exceed grade 2 in either treatment arm [10,11].

Though usually accepted to be less systematic and rigorous in evaluation of toxicity than prospective trials, multiple retrospective reviews of CWT have been performed. Bongers et al. reported on patients treated with three, five or eight fractions. CWT developed in $11.4 \%$ of patients and was severe (grade 3) in 2.0\% [30]. Similarly, treating 30 or $34 \mathrm{~Gy}$ in a single fraction, Manyam et al. reported a comparable overall grade $\geq 3$ CWT rate of $1.4 \%$ [31]. Both Bongers et al. and Manyam et al. concurred that CWT was associated with larger volumes of chest wall receiving doses of $30 \mathrm{~Gy}$ or greater.

When considering only the lesions abutting the chest wall, the $30.6 \%$ CWT rate [31] reported by Manyam et al. for single fraction is consistent with the expected grade 1-2 CWT rate of $21-34 \%[32,33]$ and rib fracture rate of up to $37 \%$ [32,34-37] observed in multi-fraction SBRT studies. For context, chronic post-operative pain from video-assisted thoracic surgery ranges from $25 \%$ to $47 \%$ [38,39]. Given that most reactions are low-grade and self-limited, location relative to the chest wall is not a contraindication for either single- or multi-fraction SBRT [31]. Consequently, the senior authors of Manyam et al. (KS and GV) do not use chest wall proximity to restrict patient eligibility for single-fraction SBRT [40]. As noted above, the updated 2022 NCCN guidelines [15] removed distance from chest wall as a factor in determining eligibility for single-fraction SBRT.

Although rare, there were three treatment-related deaths following single-fraction SBRT reported by Le et al.; all three had received prior chemotherapy and two had received prior radiation therapy [25]. Le et al. demonstrated that caution is needed when using single-fraction SBRT in patients with prior thoracic radiation and/or chemotherapy, especially with large central tumors [25]. Given the paucity of prospective studies and limited retrospective data [41], our review does not address the safety and efficacy of single-fraction SBRT for central lung tumors.

When treating pulmonary oligometastases, a review suggested favorable local control with SBRT [42]. Filippi et al. reported excellent local control and survival outcomes, making single-fraction SBRT an attractive treatment option for patients with peripherally located oligometastatic pulmonary lesions [21]. In addition, SBRT resulted in improved and durable survival benefits in the SABR-COMET trial that included $40-50 \%$ of lesions located in lungs [43,44]. However, single-fraction SBRT was not allowed in both SABR-COMET and its subsequent trial SABR-COMET-3 [43,45], while the ongoing SABR-COMET-10 trial allows 16-24 Gy of single-fraction SBRT at the treating physicians' discretion [46]. The recently completed randomized phase II SAFRON II trial [16] showed comparable toxicity profiles, local control, and patient-reported outcomes between both single $28 \mathrm{~Gy}$ and four fractions of 12 Gy SBRT.

Single-fraction SBRT is an excellent option for medically inoperable patients in early stage, peripheral NSCLC patients, and those with lung oligometastases. Beyond patient convenience (one visit for treatment versus multiple), single-fraction SBRT has additional resource utilization benefits. In the context of COVID-19, the transition to single-fraction SBRT reduces risk by minimizing patient visits and reduces personal protective equipment needs.

Unsurprisingly, in the United States, single-fraction SBRT costs less than multi-fraction SBRT. Medicare reimbursement for single-fraction SBRT is roughly half that of five-fraction SBRT. For example, in 2020, Medicare reimbursement in the western New York region for professional and technical fees was approximately USD 5600 for single-fraction SBRT, USD 7800 for three-fraction SBRT, and USD 10,000 for five-fraction SBRT. Enhanced reimburse- 
ment for multi-fraction SBRT may limit enthusiasm to adopt single fraction in the United States and other fee-for-service systems.

Furthermore, despite favorable primary tumor control seen in RTOG 0915, five-year OS remains poor at $30-40 \%$ in part due to distant metastases seen in over $40 \%$ of patients with early stage NSCLC undergoing single- or multi-fraction SBRT [11]. The optimal adjuvant therapy regimens to improve such outcomes remain unclear at this time, with numerous ongoing clinical trials evaluating the role of immunotherapy (ClinicalTrials.gov identifier: NCT03383302, NCT03446547, and NCT03110978) including PACIFIC-4/RTOG 3515 trial (NCT03833154). These studies may further provide prospective evidence on the role of single- versus multi-fraction SBRT in the setting of immunotherapy.

There are several limitations in our review. First, optimal technical approaches such as motion management and planning techniques remain unclear. For instance, RTOG 0915 allowed multiple motion managements such as abdominal compression, active breathholding techniques, and accelerator beam gating with the respiratory cycle [11]. RTOG 0915 also allowed both 3D conformal radiation therapy (3DCRT) and intensity-modulated radiation therapy (IMRT) [11]. In SAFRON II, over $60 \%$ of patients underwent 3DCRT, and select patients utilized multiple motion management techniques [16]. Given the paucity of prospective literature comparing heterogeneous motion management and planning approaches for single-fraction SBRT, we cannot draw definitive conclusions on the role of such techniques for tumor control and toxicity outcomes. Second, although normal tissue constraints for single-fraction SBRT were previously established based on RTOG 0915 [11], more prospective data with well-defined reporting standards for toxicity outcomes are necessary for further optimization as recommended by the Hypofractionated Treatment Effects in the Clinic (HyTEC) $[47,48]$. Third, although the definition of central lung location has evolved over the years with the introduction of ultra-central lung location as detailed by an ongoing multi-center phase I trial [49], the definition of peripheral lung location has not been prospectively subdivided by the lesions located near versus far away from the chest wall.

The initial Indiana University and RTOG 0236 trials [50,51] did not subclassify peripheral tumors and did not report separate outcomes for lesions abutting the chest wall or at high risk for CWT. Despite this lack of prospective multi-center, long-term outcomes for these lesions at risk for CWT, both single- and multi-fraction SBRT have been utilized with a grade $\geq 3$ CWT rate of $1-2 \%[30,31]$. Such low rates make an adequately powered prospective trial impractical. In the absence of prospective trial data, informed decision making with patients is mandatory prior to utilizing single- or multi-fraction SBRT for lesions at risk for CWT.

\section{Conclusions}

Single-fraction SBRT for early stage peripheral NSCLC and oligometastatic lung cancer is an efficacious and well-tolerated treatment including local control rates of over 90\%, favorable survival measures, and mild toxicity profiles. Given a lack of pre-specified distinction between lesions at risk for CWT versus other peripheral lesions in trials comparing single- and multi-fraction SBRT, informed decision making with patients regarding the risk of CWT is needed. This review does not support single-fraction SBRT for central lung tumors. Reducing radiation fractions while preserving treatment efficacy should be prioritized amidst the ongoing COVID-19 pandemic to mitigate disease transmission among patients and health care workers. Moreover, the encouraging outcomes, reduced resource utilization, and enhanced patient convenience of single-fraction SBRT will remain even after the current pandemic.

Author Contributions: Conceptualization, A.K.S.; methodology, A.J.B., M.M., S.J.M. and A.K.S.; validation, A.J.B., M.M., M.W.H., S.Y., G.M.M.V., K.L.S., S.S., M.K.F., S.J.M. and A.K.S.; investigation, A.J.B., M.M., M.W.H., S.Y., G.M.M.V., K.L.S., S.S., M.K.F., S.J.M. and A.K.S.; resources, A.J.B., M.M., M.W.H., S.Y., G.M.M.V., K.L.S., S.S., M.K.F., S.J.M. and A.K.S.; data curation, A.J.B., M.M. and S.J.M.; writing-original draft preparation, A.J.B., M.M. and S.J.M.; writing-review and editing, A.J.B., 
M.M., M.W.H., S.Y., G.M.M.V., K.L.S., S.S., M.K.F., S.J.M. and A.K.S.; visualization, A.J.B., M.M. and S.J.M.; supervision, M.W.H., S.Y., G.M.M.V., K.L.S., S.S. and A.K.S.; project administration, A.J.B., M.M., M.W.H., S.Y., G.M.M.V., K.L.S., S.S., M.K.F., S.J.M. and A.K.S.; funding acquisition, A.K.S. All authors have read and agreed to the published version of the manuscript.

Funding: This work was supported by the National Cancer Institute Cancer Center Support Grant (P30CA016056).

Conflicts of Interest: The authors declare no conflict of interest. The funder had no role in the design of the study; in the collection, analyses, or interpretation of data; in the writing of the manuscript; or in the decision to publish the results.

\section{References}

1. Schrag, D.; Hershman, D.L.; Basch, E. Oncology Practice During the COVID-19 Pandemic. JAMA 2020, 323, 2005-2006. [CrossRef] [PubMed]

2. Couñago, F.; Navarro-Martin, A.; Luna, J.; de Dios, N.R.; Rodríguez, A.; Casas, F.; García, R.; Gómez-Caamaño, A.; Contreras, J.; Serrano, J. GOECP/SEOR clinical recommendations for lung cancer radiotherapy during the COVID-19 pandemic. World J. Clin. Oncol. 2020, 11, 510-527. [CrossRef]

3. Ng, S.S.W.; Ning, M.S.; Lee, P.; McMahon, R.A.; Siva, S.; Chuong, M.D. Single-Fraction Stereotactic Body Radiation Therapy: A Paradigm During the Coronavirus Disease 2019 (COVID-19) Pandemic and Beyond? Adv. Radiat. Oncol. 2020, 5, 761-773. [CrossRef] [PubMed]

4. Salama, J.K.; Giuliani, M.E.; Robinson, C.G.; Daly, M.E. Single-fraction SBRT for Early Stage NSCLC-A Viable Option in “These Uncertain Times"? Int. J. Radiat. Oncol. Biol. Phys. 2021, 109, 1-4. [CrossRef] [PubMed]

5. Simcock, R.; Thomas, T.V.; Estes, C.; Filippi, A.R.; Katz, M.S.; Pereira, I.J.; Saeed, H. COVID-19: Global radiation oncology's targeted response for pandemic preparedness. Clin. Transl. Radiat. Oncol. 2020, 22, 55-68. [CrossRef] [PubMed]

6. Thomson, D.J.; Yom, S.S.; Saeed, H.; El Naqa, I.; Ballas, L.; Bentzen, S.M.; Chao, S.T.; Choudhury, A.; Coles, C.E.; Dover, L.; et al. Radiation Fractionation Schedules Published During the COVID-19 Pandemic: A Systematic Review of the Quality of Evidence and Recommendations for Future Development. Int. J. Radiat. Oncol. Biol. Phys. 2020, 108, 379-389. [CrossRef]

7. Lindberg, K.; Nyman, J.; Riesenfeld Källskog, V.; Hoyer, M.; Lund, J.Å.; Lax, I.; Wersäll, P.; Karlsson, K.; Friesland, S.; Lewensohn, R. Long-term results of a prospective phase II trial of medically inoperable stage I NSCLC treated with SBRT-The Nordic experience. Acta Oncol. 2015, 54, 1096-1104. [CrossRef]

8. Verstegen, N.E.; Lagerwaard, F.J.; Hashemi, S.M.; Dahele, M.; Slotman, B.J.; Senan, S. Patterns of Disease Recurrence after SABR for Early Stage Non-Small-Cell Lung Cancer: Optimizing Follow-Up Schedules for Salvage Therapy. J. Thorac. Oncol. 2015, 10, 1195-1200. [CrossRef] [PubMed]

9. Postmus, P.E.; Kerr, K.M.; Oudkerk, M.; Senan, S.; Waller, D.A.; Vansteenkiste, J.; Escriu, C.; Peters, S. Early and locally advanced non-small-cell lung cancer (NSCLC): ESMO Clinical Practice Guidelines for diagnosis, treatment and follow-up. Ann. Oncol. 2017, 28, iv1-iv21. [CrossRef]

10. Singh, A.K.; Gomez-Suescun, J.A.; Stephans, K.L.; Bogart, J.A.; Hermann, G.M.; Tian, L.; Groman, A.; Videtic, G.M. One Versus Three Fractions of Stereotactic Body Radiation Therapy for Peripheral Stage I to II Non-Small Cell Lung Cancer: A Randomized, Multi-Institution, Phase 2 Trial. Int. J. Radiat. Oncol. Biol. Phys. 2019, 105, 752-759. [CrossRef]

11. Videtic, G.M.; Paulus, R.; Singh, A.K.; Chang, J.Y.; Parker, W.; Olivier, K.R.; Timmerman, R.D.; Komaki, R.R.; Urbanic, J.J.; Stephans, K.L.; et al. Long-term Follow-up on NRG Oncology RTOG 0915 (NCCTG N0927): A Randomized Phase 2 Study Comparing 2 Stereotactic Body Radiation Therapy Schedules for Medically Inoperable Patients With Stage I Peripheral Non-Small Cell Lung Cancer. Int. J. Radiat. Oncol. Biol. Phys. 2019, 103, 1077-1084. [CrossRef] [PubMed]

12. Cummings, M.A.; Ma, S.J.; Hermann, G.; Serra, L.; Syed, Y.; Malhotra, H.K.; Chen, Y.; Milano, M.T.; Gomez-Suescun, J.A.; Singh, D.P.; et al. Comparison of Single- and Five-fraction Regimens of Stereotactic Body Radiation Therapy for Peripheral Early-stage Non-small-cell Lung Cancer: A Two-institution Propensity-matched Analysis. Clin. Lung Cancer 2018, 19, 511-517. [CrossRef] [PubMed]

13. Ma, S.J.; Cummings, M.; Serra, L.M.; Syed, Y.A.; Hermann, G.M.; Chen, Y.; Milano, M.T.; Singh, A.K.; Gomez-Suescun, J.A.; Singh, D.P. Three- Versus Five-Fraction Regimens of Stereotactic Body Radiotherapy for Peripheral Early-Stage Non-Small-Cell Lung Cancer: A Two-Institution Propensity Score-Matched Analysis. Clin. Lung Cancer 2018, 19, e297-e302. [CrossRef]

14. Ma, S.J.; Serra, L.M.; Syed, Y.A.; Hermann, G.M.; Gomez-Suescun, J.A.; Singh, A.K. Comparison of Single- and Three-fraction Schedules of Stereotactic Body Radiation Therapy for Peripheral Early-stage Non-Small-cell Lung Cancer. Clin. Lung Cancer 2018, 19, e235-e240. [CrossRef] [PubMed]

15. National Comprehensive Cancer Network. Non-Small Cell Lung Cancer (Version 1.2022). Available online: https:/ / www.nccn org/professionals/physician_gls/pdf/nscl.pdf (accessed on 21 January 2022).

16. Siva, S.; Bressel, M.; Mai, T.; Le, H.; Vinod, S.; de Silva, H.; Macdonald, S.; Skala, M.; Hardcastle, N.; Rezo, A.; et al. Single-Fraction vs Multifraction Stereotactic Ablative Body Radiotherapy for Pulmonary Oligometastases (SAFRON II): The Trans Tasman Radiation Oncology Group 13.01 Phase 2 Randomized Clinical Trial. JAMA Oncol. 2021, 7, 1476-1485. [CrossRef] 
17. Lewis, S.L.; Porceddu, S.; Nakamura, N.; Palma, D.A.; Lo, S.S.; Hoskin, P.; Moghanaki, D.; Chmura, S.J.; Salama, J.K. Definitive Stereotactic Body Radiotherapy (SBRT) for Extracranial Oligometastases: An International Survey of $>1000$ Radiation Oncologists. Am. J. Clin. Oncol. 2017, 40, 418-422. [CrossRef]

18. Mou, B.; Hyde, D.; Araujo, C.; Bartha, L.; Bergman, A.; Liu, M. Implementation of Single-Fraction Lung Stereotactic Ablative Radiotherapy in a Multicenter Provincial Cancer Program During the COVID-19 Pandemic. Cureus 2021, 13, e15598. [CrossRef]

19. Nagata, Y.; Ozawa, S.; Nakao, M.; Kawahara, D.; Kimura, T.; Murakami, Y. Survey of stereotactic body radiation therapy in Japan. Int. J. Radiat. Oncol. Biol. Phys. 2020, 108, E449. [CrossRef]

20. Page, M.J.; McKenzie, J.E.; Bossuyt, P.M.; Boutron, I.; Hoffmann, T.C.; Mulrow, C.D.; Shamseer, L.; Tetzlaff, J.M.; Akl, E.A.; Brennan, S.E.; et al. The PRISMA 2020 statement: An updated guideline for reporting systematic reviews. BMJ 2021, 372, n71. [CrossRef]

21. Filippi, A.R.; Badellino, S.; Guarneri, A.; Levis, M.; Botticella, A.; Mantovani, C.; Ragona, R.; Racca, P.; Buffoni, L.; Novello, S.; et al. Outcomes of single fraction stereotactic ablative radiotherapy for lung metastases. Technol. Cancer Res. Treat. 2014, 13, 37-45. [CrossRef]

22. Fritz, P.; Kraus, H.J.; Mühlnickel, W.; Hammer, U.; Dölken, W.; Engel-Riedel, W.; Chemaissani, A.; Stoelben, E. Stereotactic, single-dose irradiation of stage I non-small cell lung cancer and lung metastases. Radiat. Oncol. 2006, 1, 30. [CrossRef] [PubMed]

23. Hof, H.; Herfarth, K.K.; Münter, M.; Hoess, A.; Motsch, J.; Wannenmacher, M.; ürgen Debus, J. Stereotactic single-dose radiotherapy of stage I non-small-cell lung cancer (NSCLC). Int. J. Radiat. Oncol. Biol. Phys. 2003, 56, 335-341. [CrossRef]

24. Hof, H.; Hoess, A.; Oetzel, D.; Debus, J.; Herfarth, K. Stereotactic single-dose radiotherapy of lung metastases. Strahlenther. Onkol. 2007, 183, 673-678. [CrossRef] [PubMed]

25. Le, Q.T.; Loo, B.W.; Ho, A.; Cotrutz, C.; Koong, A.C.; Wakelee, H.; Kee, S.T.; Constantinescu, D.; Whyte, R.I.; Donington, J. Results of a phase I dose-escalation study using single-fraction stereotactic radiotherapy for lung tumors. J. Thorac. Oncol. 2006, 1, 802-809. [CrossRef]

26. Whyte, R.I.; Crownover, R.; Murphy, M.J.; Martin, D.P.; Rice, T.W.; DeCamp, M.M., Jr.; Rodebaugh, R.; Weinhous, M.S.; Le, Q.T. Stereotactic radiosurgery for lung tumors: Preliminary report of a phase I trial. Ann. Thorac. Surg. 2003, 75, 1097-1101. [CrossRef]

27. Faivre-Finn, C.; Fenwick, J.D.; Franks, K.N.; Harrow, S.; Hatton, M.Q.; Hiley, C.; McAleese, J.J.; McDonald, F.; O’Hare, J.; Peedell, C.; et al. Reduced Fractionation in Lung Cancer Patients Treated with Curative-intent Radiotherapy during the COVID-19 Pandemic. Clin. Oncol. 2020, 32, 481-489. [CrossRef]

28. Guckenberger, M.; Belka, C.; Bezjak, A.; Bradley, J.; Daly, M.E.; DeRuysscher, D.; Dziadziuszko, R.; Faivre-Finn, C.; Flentje, M.; Gore, E.; et al. Practice recommendations for lung cancer radiotherapy during the COVID-19 pandemic: An ESTRO-ASTRO consensus statement. Radiother. Oncol. 2020, 146, 223-229. [CrossRef]

29. Daly, M.E.; Perks, J.R.; Chen, A.M. Patterns-of-care for thoracic stereotactic body radiotherapy among practicing radiation oncologists in the United States. J. Thorac. Oncol. 2013, 8, 202-207. [CrossRef]

30. Bongers, E.M.; Haasbeek, C.J.; Lagerwaard, F.J.; Slotman, B.J.; Senan, S. Incidence and risk factors for chest wall toxicity after risk-adapted stereotactic radiotherapy for early-stage lung cancer. J. Thorac. Oncol. 2011, 6, 2052-2057. [CrossRef]

31. Manyam, B.V.; Videtic, G.M.M.; Verdecchia, K.; Reddy, C.A.; Woody, N.M.; Stephans, K.L. Effect of Tumor Location and Dosimetric Predictors for Chest Wall Toxicity in Single-Fraction Stereotactic Body Radiation Therapy for Stage I Non-Small Cell Lung Cancer. Pract. Radiat. Oncol. 2019, 9, e187-e195. [CrossRef]

32. Nambu, A.; Onishi, H.; Aoki, S.; Tominaga, L.; Kuriyama, K.; Araya, M.; Saito, R.; Maehata, Y.; Komiyama, T.; Marino, K.; et al. $\mathrm{Rib}$ fracture after stereotactic radiotherapy for primary lung cancer: Prevalence, degree of clinical symptoms, and risk factors. BMC Cancer 2013, 13, 68. [CrossRef]

33. Stephans, K.L.; Djemil, T.; Tendulkar, R.D.; Robinson, C.G.; Reddy, C.A.; Videtic, G.M. Prediction of chest wall toxicity from lung stereotactic body radiotherapy (SBRT). Int. J. Radiat. Oncol. Biol. Phys. 2012, 82, 974-980. [CrossRef] [PubMed]

34. Aoki, M.; Sato, M.; Hirose, K.; Akimoto, H.; Kawaguchi, H.; Hatayama, Y.; Ono, S.; Takai, Y. Radiation-induced rib fracture after stereotactic body radiotherapy with a total dose of 54-56 Gy given in 9-7 fractions for patients with peripheral lung tumor: Impact of maximum dose and fraction size. Radiat. Oncol. 2015, 10, 99. [CrossRef]

35. Asai, K.; Shioyama, Y.; Nakamura, K.; Sasaki, T.; Ohga, S.; Nonoshita, T.; Yoshitake, T.; Ohnishi, K.; Terashima, K.; Matsumoto, K.; et al. Radiation-induced rib fractures after hypofractionated stereotactic body radiation therapy: Risk factors and dose-volume relationship. Int. J. Radiat. Oncol. Biol. Phys. 2012, 84, 768-773. [CrossRef] [PubMed]

36. Park, Y.; Kim, H.J.; Chang, A.R. Predictors of chest wall toxicity after stereotactic ablative radiotherapy using real-time tumor tracking for lung tumors. Radiat. Oncol. 2017, 12, 66. [CrossRef] [PubMed]

37. Taremi, M.; Hope, A.; Lindsay, P.; Dahele, M.; Fung, S.; Purdie, T.G.; Jaffray, D.; Dawson, L.; Bezjak, A. Predictors of radiotherapy induced bone injury (RIBI) after stereotactic lung radiotherapy. Radiat. Oncol. 2012, 7, 159. [CrossRef]

38. Bayman, E.O.; Parekh, K.R.; Keech, J.; Selte, A.; Brennan, T.J. A Prospective Study of Chronic Pain after Thoracic Surgery. Anesthesiology 2017, 126, 938-951. [CrossRef]

39. Steegers, M.A.; Snik, D.M.; Verhagen, A.F.; van der Drift, M.A.; Wilder-Smith, O.H. Only half of the chronic pain after thoracic surgery shows a neuropathic component. J. Pain 2008, 9, 955-961. [CrossRef]

40. Videtic, G.M.M.; Reddy, C.A.; Woody, N.M.; Stephans, K.L. Ten-Year Experience in Implementing Single-Fraction Lung SBRT for Medically Inoperable Early-Stage Lung Cancer. Int. J. Radiat. Oncol. Biol. Phys. 2021, 111, 436-442. [CrossRef] 
41. Ma, S.J.; Syed, Y.A.; Rivers, C.I.; Suescun, J.A.G.; Singh, A.K. Comparison of single- and five-fraction schedules of stereotactic body radiation therapy for central lung tumours: A single institution experience. J. Radiother. Pract. 2017, 16, 148-154. [CrossRef]

42. Siva, S.; Slotman, B.J. Stereotactic Ablative Body Radiotherapy for Lung Metastases: Where is the Evidence and What are We Doing With It? Semin. Radiat. Oncol. 2017, 27, 229-239. [CrossRef]

43. Palma, D.A.; Olson, R.; Harrow, S.; Gaede, S.; Louie, A.V.; Haasbeek, C.; Mulroy, L.; Lock, M.; Rodrigues, G.B.; Yaremko, B.P.; et al. Stereotactic ablative radiotherapy versus standard of care palliative treatment in patients with oligometastatic cancers (SABR-COMET): A randomised, phase 2, open-label trial. Lancet 2019, 393, 2051-2058. [CrossRef]

44. Palma, D.A.; Olson, R.A.; Harrow, S.; Gaede, S.; Louie, A.V.; Haasbeek, C.; Mulroy, L.; Lock, M.I.; Rodrigues, G.; Yaremko, B.P.; et al. Stereotactic Ablative Radiotherapy for the Comprehensive Treatment of Oligometastatic Cancers: Long-Term Results of the SABR-COMET Phase II Randomized Trial. J. Clin. Oncol. 2020, 38, 2830-2838. [CrossRef] [PubMed]

45. Olson, R.; Mathews, L.; Liu, M.; Schellenberg, D.; Mou, B.; Berrang, T.; Harrow, S.; Correa, R.J.; Bhat, V.; Pai, H.; et al. Stereotactic ablative radiotherapy for the comprehensive treatment of 1-3 Oligometastatic tumors (SABR-COMET-3): Study protocol for a randomized phase III trial. BMC Cancer 2020, 20, 380. [CrossRef] [PubMed]

46. Palma, D.A.; Olson, R.; Harrow, S.; Correa, R.J.; Schneiders, F.; Haasbeek, C.J.; Rodrigues, G.B.; Lock, M.; Yaremko, B.P.; Bauman, G.S.; et al. Stereotactic ablative radiotherapy for the comprehensive treatment of 4-10 oligometastatic tumors (SABR-COMET-10): Study protocol for a randomized phase III trial. BMC Cancer 2019, 19, 816. [CrossRef] [PubMed]

47. Moiseenko, V.; Zhao, J.; Milano, M.T.; Li, L.; Rimner, A.; Das, S.; Li, X.A.; Miften, M.; Liao, Z.; Martel, M.; et al. Organs at Risk Considerations for Thoracic Stereotactic Body Radiation Therapy: What Is Safe for Lung Parenchyma? Int. J. Radiat. Oncol. Biol. Phys. 2021, 110, 172-187.

48. Lee, P.; Loo, B.W., Jr.; Biswas, T.; Ding, G.X.; El Naqa, I.M.; Jackson, A.; Kong, F.M.; LaCouture, T.; Miften, M.; Solberg, T.; et al. Local Control After Stereotactic Body Radiation Therapy for Stage I Non-Small Cell Lung Cancer. Int. J. Radiat. Oncol. Biol. Phys. 2021, 110, 160-171. [CrossRef] [PubMed]

49. Giuliani, M.; Mathew, A.S.; Bahig, H.; Bratman, S.V.; Filion, E.; Glick, D.; Louie, A.V.; Raman, S.; Swaminath, A.; Warner, A.; et al. SUNSET: Stereotactic Radiation for Ultracentral Non-Small-Cell Lung Cancer-A Safety and Efficacy Trial. Clin. Lung Cancer 2018, 19, e529-e532. [CrossRef] [PubMed]

50. Fakiris, A.J.; McGarry, R.C.; Yiannoutsos, C.T.; Papiez, L.; Williams, M.; Henderson, M.A.; Timmerman, R. Stereotactic body radiation therapy for early-stage non-small-cell lung carcinoma: Four-year results of a prospective phase II study. Int. J. Radiat. Oncol. Biol. Phys. 2009, 75, 677-682. [CrossRef]

51. Timmerman, R.; Paulus, R.; Galvin, J.; Michalski, J.; Straube, W.; Bradley, J.; Fakiris, A.; Bezjak, A.; Videtic, G.; Johnstone, D.; et al. Stereotactic body radiation therapy for inoperable early stage lung cancer. JAMA 2010, 303, 1070-1076. [CrossRef] [PubMed] 